\title{
APLIKASI PENGOLAHAN CITRA UNTUK MENDETEKSI FRAKTUR TULANG DENGAN METODE DETEKSI TEPI CANNY
}

\author{
${ }^{\# 1}$ Puji Triono, ${ }^{\# 2}$ Murinto \\ Program Studi Teknik InformatikaUniversitas Ahmad Dahlan \\ Jl. Prof. Dr. Soepomo, Telp. (0274) 379418 \\ email : pujexcarlox@gmail.com ${ }^{\# 1}$, murintokusno@ tif.uad.ac.id ${ }^{\# 2}$
}

\begin{abstract}
Abstrak
Tulang merupakan salah satu anggota tubuh yang sangat penting bagi manusia, sehingga kerusakan pada tulang sangat berpengaruh pada keadaan tubuh manusia. Salah satu jenis kecacatan/kerusakan pada tulang yang kerap dijumpai adalah fraktur. Fraktur adalah keadaan dimana tulang mengalami retak atau patah. Karena letak tulang yang berada didalam tubuh, maka perlu dilakukan pemotretan dengan sinar-X untuk melihat kondisi tulang. Gambar dari pemotretan tersebut yang akan digunakan petugas medis dalam pemeriksaan tulang. Pemeriksaan dilakukan dengan cara mengamati gambar secara langsung dengan menggunakan kemampuan visual petugas medis. Proses pemeriksaan inilah yang sangat membutuhkan konsentrasi dan ketelitian. Untuk menangani permasalahan tersebut dapat digunakan sebuah aplikasi pengolahan citra untuk mendeteksi fraktur pada tulang dengan metode Canny. Metode Canny sangat baik untuk mendeteksi tepi karena memenuhi syarat pendeteksi tepian paling optimum, yakni: mendeteksi dengan baik (kriteria deteksi), melokalisasi dengan baik (kriteria lokalisasi), dan respon yang baik (kriteria respon). Dalam penelitian ini dilakukan perancangan aplikasi pengolahan citra untuk mendeteksi fraktur pada tulang dengan metode Canny. Citra yang digunakan adalah citra hasil scan tulang paha menggunakan sinar-X dengan posisi Lateral dan Antero Posterior (AP). Untuk pengambilan keputusan menggunakan uji kstest2. Perangkat lunak yang digunakan untuk membangun aplikasi ini adalah matlab R2013a. Data yang digunakan dalam penelitian ini terdiri dari 8 citra standar dan 29 citra uji. Untuk citra standar tulang paha dengan posisi Lateral dan Antero Posterior masing-masing digunakan sebanyak 4 citra. Sedangkan untuk citra uji sebanyak 15 citra untuk tulang paha dengan posisi Antero Posterior dan 14 citra untuk posisi Lateral. Hasil dari penelitian ini adalah suatu aplikasi pengolahan citra untuk mendeteksi fraktur pada tulang dengan metode Canny. Aplikasi ini mampu mendeteksi tepian objek pada citra kemudian mampu memberikan keputusan bahwa tulang mengalami fraktur atau tidak. Hasil pengujian sistem menunjukan nilai akurasi deteksi pada citra tulang paha dengan posisi Antero Posterior adalah $80 \%$ dan citra tulang paha dengan posisi Lateral adalah 85,71\%.
\end{abstract}

Kata kunci : Antero Posterior, Fraktur Tulang, Lateral, Metode Canny, Uji kstest2.

\section{PENDAHULUAN}

Tulang adalah salah satu bagian tubuh manusia yang paling penting. Fungsi tulang sendiri adalah sebagai kerangka, penopang tubuh manusia dan tempat melekatnya otot, sehingga tubuh dapat bergerak maksimal. Tidak hanya itu, beberapa bagian tulang juga memiliki fungsi untuk melindungi organ lain didalam tubuh. Seperti tulang tengkorak yang berfungsi melindungi otak dari berbagai macam benturan dari luar, susunan tulang rusuk yang berfungsi untuk melindungi paru-paru dan sebagainya. Itulah yang menjadikan fungsi tulang menjadi sangat vital apabila terjadi kerusakan pada tulang itu sendiri.

Badan kesehatan dunia (WHO) mencatat tahun 2007 terdapat lebih dari delapan juta orang meninggal dikarenakan insiden kecelakaan dan sekitar 2 juta orang mengalami kecacatan fisik. Salah satu insiden kecelakaan yang memiliki angka kejadian yang cukup tinggi yakni insiden fraktur ekstremitas bawah yakni sekitar 46,2\% dari insiden kecelakaan yang terjadi. Berdasarkan hasil Riset Kesehatan Dasar (RISKESDAS) oleh Badan Penelitian dan Pengembangan Depkes RI tahun 2007 di Indonesia terjadi kasus fraktur yang disebabkan oleh cedera antara lain karena jatuh, kecelakaan lalu lintas dan trauma 
benda tajam/tumpul. Dari 45.987 peristiwa terjatuh yang mengalami fraktur sebanyak 1.775 orang $(3,8 \%)$, dari 20.829 kasus kecelakaan lalu lintas, yang mengalami fraktur sebanyak 1.770 orang $(8,5 \%)$, dari 14.127 trauma benda tajam/ tumpul, yang mengalami fraktur sebanyak 236 orang (1,7\%). Berdasarkan data dari Dinas Kesehatan Provinsi Jawa Tengah tahun 2007 didapatkan sekitar 2.700 orang mengalami insiden fraktur, 56\% penderita mengalami kecacatan fisik, 24\% mengalami kematian, $15 \%$ mengalami kesembuhan dan 5\% mengalami gangguan psikologis atau depresi terhadap adanya kejadian fraktur. Menurut data dari Sistem Informasi Rumah Sakit (SIRS) 2010, kasus patah tulang mengalami peningkatan setiap tahun sejak 2007. Pada 2007 ada 22.815 insiden patah tulang, pada 2008 menjadi 36.947, 2009 jadi 42.280 dan pada 2010 ada 43.003 kasus. Dari data tersebut didapatkan rata-rata angka insiden patah tulang paha atas tercatat sekitar 200/100.000 pada perempuan dan laki-laki di atas usia 40 tahun. Sedangkan menurut Badan Kesehatan Dunia (WHO) $50 \%$ patah tulang paha atas akan menimbulkan kecacatan seumur hidup, dan 30\% bisa menyebabkan kematian (Noviardi, 2012).

Pengembangan Sinar-X untuk merekam dan meneliti keadaan tubuh manusia merupakan salah satu terobosan yang sangat penting dalam bidang kedokteran. Menggunakan bantuan Sinar-X dapat digambarkan bagaimana keadaan tubuh dan tulang sesorang. Melalui citra yang dihasilkan dari proses scan menggunakan Sinar-X, keadaan tulang dapat dianalisis apakah terjadi kerusakan ataupun tidak. Jenis, letak maupun intensitas kerusakannya juga dapat diketahui. Namun sayangnya saat ini proses identifikasi masih menggunakan cara manual (konvensional). Selama ini tenaga medis bidang radiologi masih mengandalkan kemampuan visualnya dalam menganalisis kerusakan yang terjadi pada tulang, padahal kemampuan visual manusia masih terbatas.

Perkembangan teknologi dewasa ini membuat sistem komputer memiliki kemampuan komputasi tinggi untuk meningkatkan pengolahan data menjadi sebuah informasi. Salah satu data tersebut dapat berupa data gambar atau citra digital yang mampu diolah untuk mendapatkan informasi yang lebih baik dan efisien, sehingga mengurangi pengaruh subyektivitas dari penggunanya.

Dari sini akan dibahas sebuah penelitian yang dimaksudkan untuk membangun sebuah alat bantu yang dapat digunakan untuk mendeteksi kerusakan (fraktur) pada tulang, sehingga dapat diketahui apakah sebuah tulang mengalami kerusakan ataupun tidak. Maka "Aplikasi Pengolahan Citra untuk Mendeteksi Fraktur pada Tulang dengan Metode Canny" akan diajukan pada penelitian ini.

\section{KAJIAN PUSTAKA}

\subsection{Deteksi Tepi}

Faktor kunci dalam mengekstraksi ciri adalah kemampuan mendeteksi keberadaan tepi (edge) dari objek di dalam citra. Pendeteksian tepi merupakan langkah pertama untuk melingkupi informasi di dalam citra. Tepi mencirikan batas-batas objek dan karena itu tepi berguna untuk proses segmentasi dan identifikasi di dalam citra. Tujuan pendeteksian tepi adalah untuk meningkatkan penampakan garis batas suatu daerah atau objek di dalam citra.

Algoritma Canny berjalan dalam 5 langkah yang terpisah yaitu:

1. Smoothing: Mengaburkan gambar untuk menghilangkan noise.

2. Finding gradien: Tepian harus ditandai pada gambar yang memiliki gradien yang besar.

3. Non-maksimum-suppresion: Hanya maxima lokal yang harus ditandai sebagai tepi.

4. Edge Tracking by hysteresis: Tepian final ditentukan dengan menekan semua sisi yang tidak terhubung dengan tepian yang sangat kuat.

\subsection{Uji Kolmogorov Smirnov}

Uji Kolmogorov Smirnov tergolong uji non parametrik. Uji non parametrik digunakan jika data yang diuji tidak mengikuti distribusi normal. Fraktur pada tulang tidak mengikuti pola distribusi normal sehingga pada penelitian ini digunakan uji Kolmogorov Smirnov untuk pengambilan keputusan.

Prinsip dari uji Kolmogorov Smirnov dua sampel ini adalah sangat sederhana, yakni jika hipotesis nihil yang mengatakan bahwa dua sample independen diambil dari populasi-populasi yang identik itu benar, maka dapat diharapkan bahwa distribusi frekuensi kumulatif dari dua sampel tersebut akan cenderung sama. Oleh karena itu uji Kolmogorov Smirnov dua sampel ini didasarkan pada nilai selisih maksimum (D maks) dari dua distribusi frekuensi kumulatifnya. Apabila selisih maksimum ini lebih 
besar daripada nilai selisih yang diharapkan (teoritis) ini berarti bahwa kesenjangan antara dua distribusi tersebut cukup besar sehingga hipotesis nihil ditolak (Djarwanto, 2007).

\section{METODE PENELITIAN}

\subsection{Subjek Penelitian}

Data dalam penelitian ini menggunakan sample citra tulang paha yang berekstensi JPEG berukuran 256 x 256 pixel.

\subsection{Metode Pengumpulan Data}

Dalam penelitian ini teknik pengumpulan data yang dilakukan adalah:

1. Metode Kepustakaan

Mengumpulkan, mempelajari dan memahami buku-buku referensi dan laporan tugas akhir yang berhubungan dengan penelitian ini.

2. Metode Observasi

Observasi yaitu pengumpulan data dengan cara pengamatan langsung pada objek yang diteliti untuk mendapatkan data yang dibutuhkan serta pengambilan data secara langsung, terutama data yang berkaitan dengan citra hasil scan menggunakan Sinar-X.

3. Browsing internet

Metode ini menggunakan internet sebagai referensi pencarian data mengenai segala hal yang berkaitan dengan penelitian.

\subsection{Perancangan Sistem}

Perancangan flowchart dari aplikasi deteksi fraktur pada tulang menggunakan metode Canny seperti diperlihatkan dalam Gambar 1 dan Gambar 2.

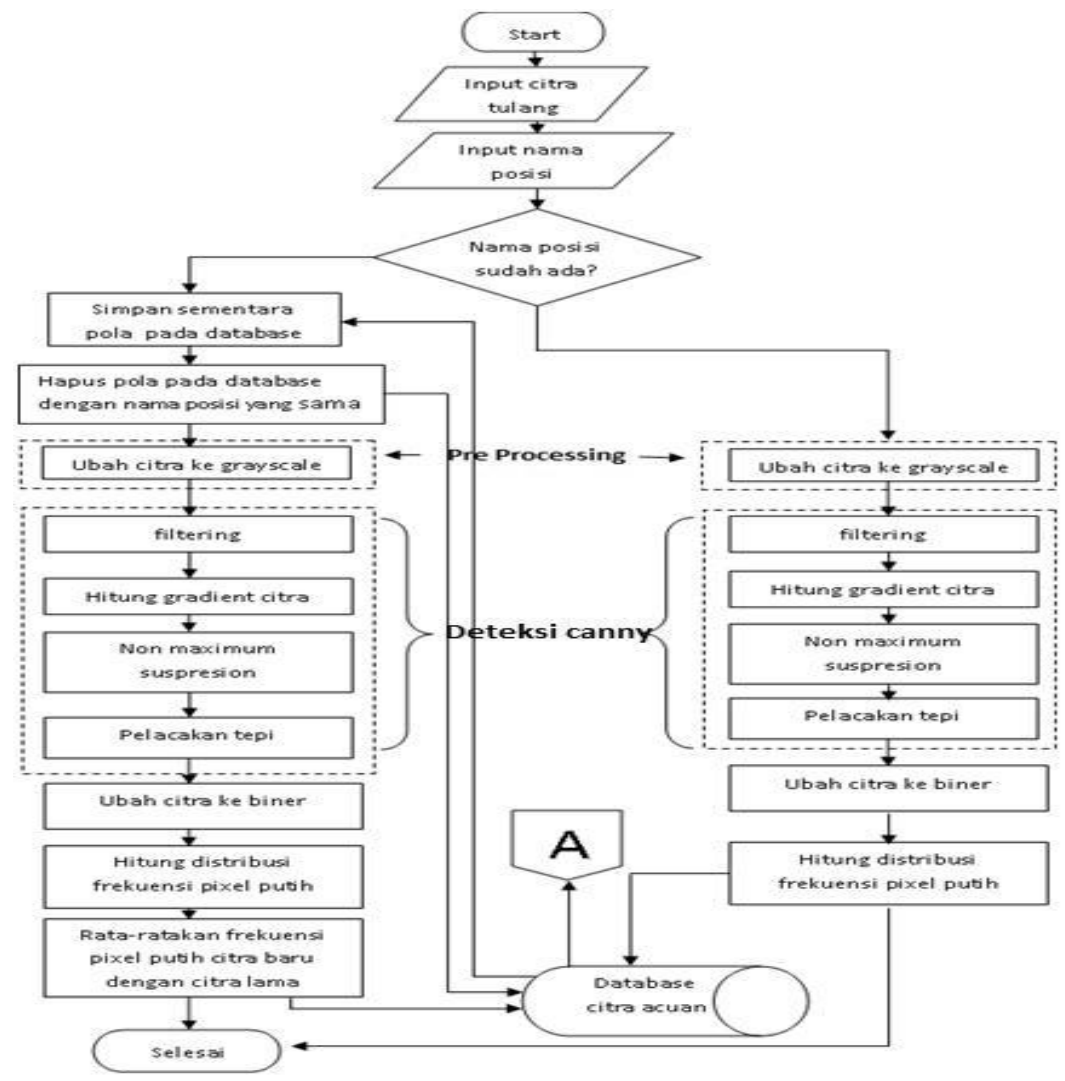

Gambar 1. Flowchart proses pembuatan template 


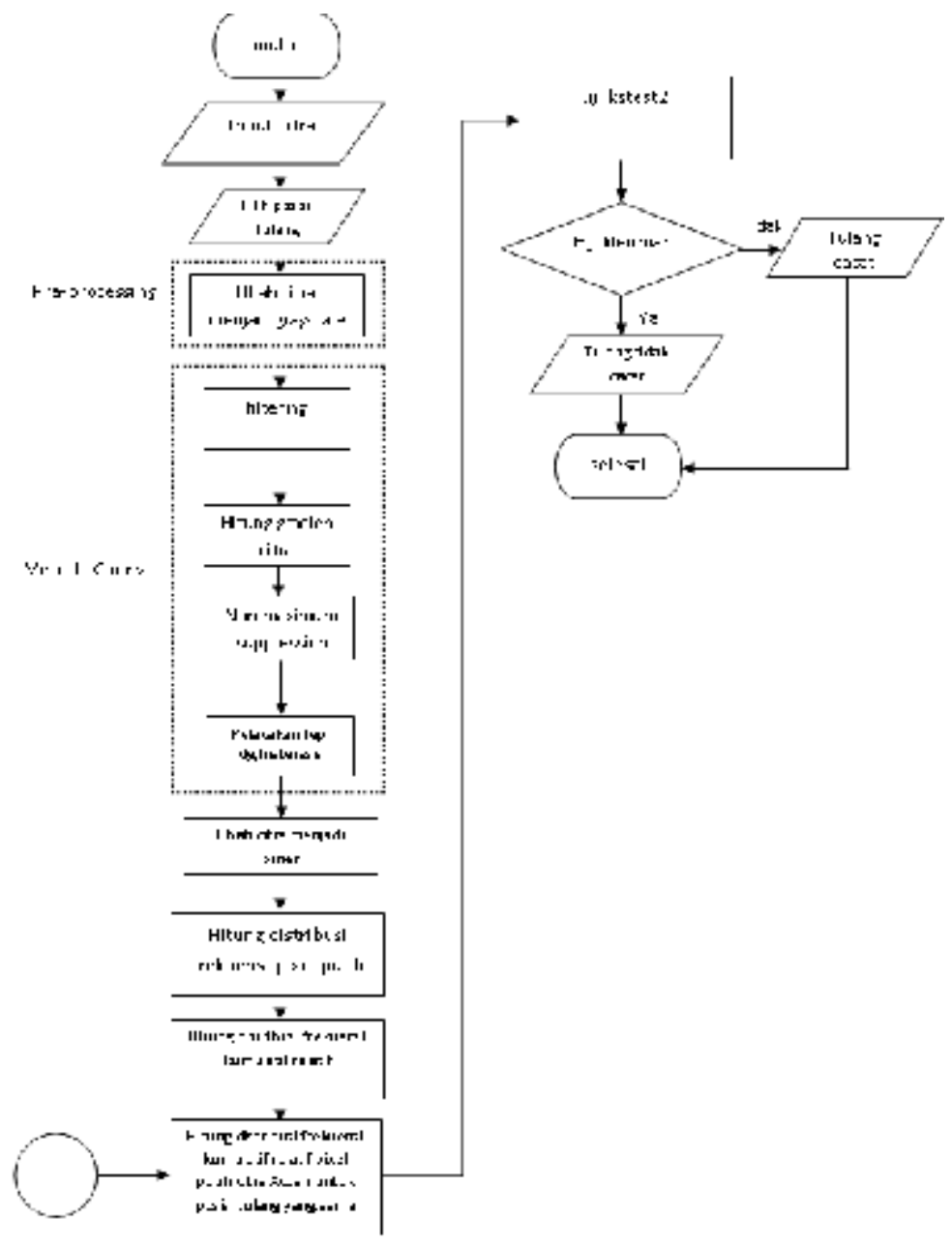

Gambar 2. Flowchart proses pengujian

\section{HASIL PENELITIAN DAN PEMBAHASAN}

\subsection{Analisis Kebutuhan Sistem}

Sistem yang akan dibangun guna memenuhi kebutuhan pengguna, antara lain kebutuhan tersebut meliputi :

1. Aplikasi dapat membaca citra berekstensi *.jpg.

2. Aplikasi dapat menampilkan citra hasil deteksi tepi.

3. Aplikasi dapat menampilkan grafik distribusi frekuensi pixel putih dari citra input.

4. Aplikasi dapat menampilkan grafik distribusi frekuensi pixel putih dari citra acuan.

5. Aplikasi dapat menampilkan grafik distribusi frekuensi kumulatif relatif.

6. Aplikasi dapat menampilkan hasil keputusan tulang paha mengalami kerusakan/cacat atau tidak.

7. Aplikasi dapat digunakan untuk pembuatan data acuan.

8. Aplikasi dapat menghapus data acuan

Dalam Tabel 1 diperlihatkan informasi data citra tulang paha yang digunakan dalam penelitian ini: 
Tabel 1. Informasi Data Citra Tulang Paha

\begin{tabular}{|l|l|l|l|l|}
\hline Citra Tulang Paha & Jumlah Citra & Citra Acuan & Citra Uji & Format \\
\hline Posisi Antero Posterior & 19 citra & 4 Citra & 15 Citra & .jpg \\
\hline Posisi Lateral & 18 citra & 4 Citra & 14 Citra & .jpg \\
\hline Total & 37 Citra & 8 Citra & 29 Citra & \\
\hline
\end{tabular}

\subsection{Implementasi Sistem}

Ketika aplikasi di jalankan untuk pertama kali maka akan terlihat seperti pada Gambar 3 berikut ini:

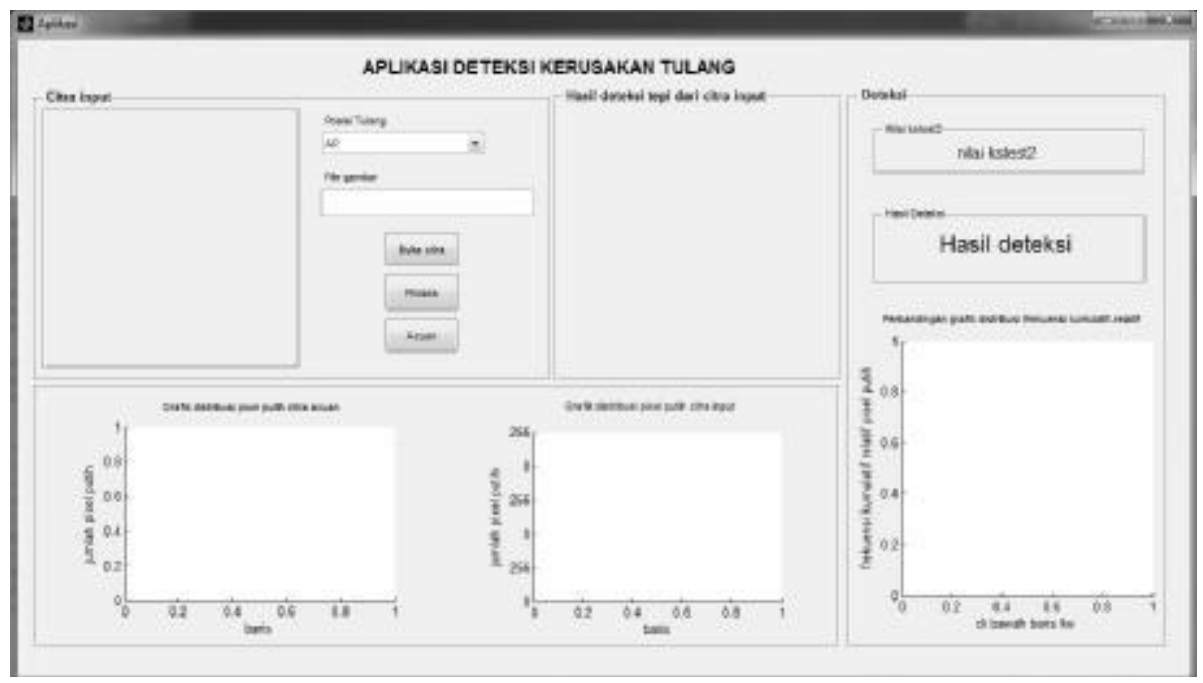

Gambar 3. Tampilan Halaman Utama Aplikasi

Proses pengujian meliputi:

1. Buka Citra

Buka citra digunakan untuk memilih citra uji dari komputer. Citra yang dapat dibaca sistem adalah citra berekstensi .jpg.

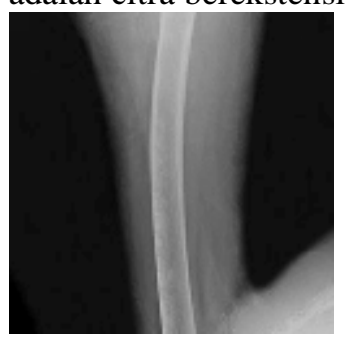

(a)

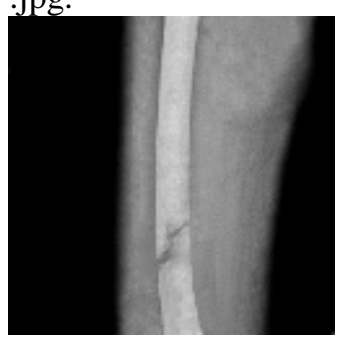

(b)

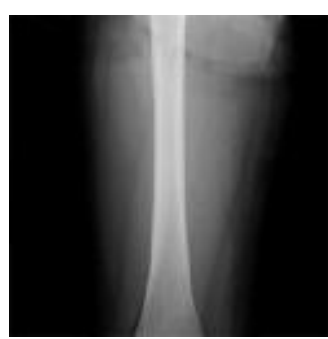

(c)

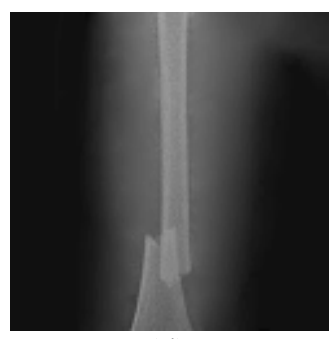

(d)

Gambar 3. Gambar citra tulang paha untuk penelitian (a) Citra tulang paha lateral normal/tidak cacat, (b) Citra tulang paha lateral cacat, (c) Citra tulang paha AP (Antero Posterior) normal/tidak cacat, (d) Citra tulang paha AP (Antero Posterior) cacat

2. Ubah citra menjadi grayscale

Citra yang telah dipilih kemudian akan diubah menjadi keabuan (grayscale). Proses ini bertujuan untuk memudahkan dalam proses yag selanjutnya, yaitu deteksi tepi. Berikut adalah contoh citra tulang paha yang telah diubah menjadi grayscale seperti yang diperlihatkan dalam Gambar 4. 


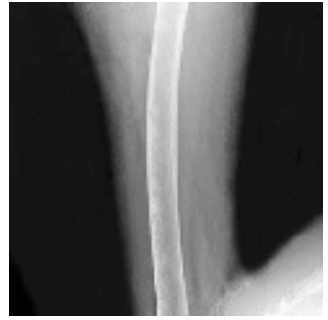

(a)

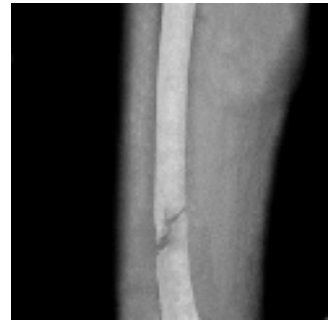

(b)

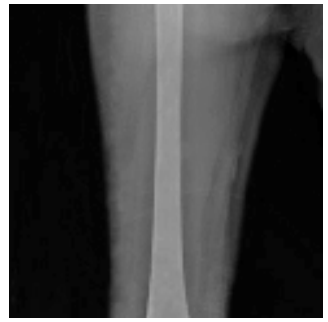

(c)

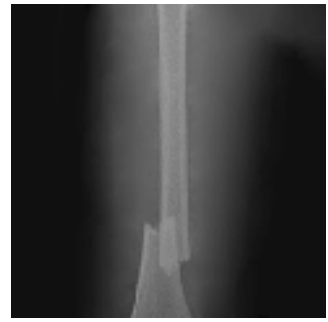

(d)

Gambar 4. Citra grayscale (a) posisi lateral tidak cacat, (b) posisi lateral cacat, (c) posisi AP tidak cacat, (d) Posisi AP cacat

3. Proses Deteksi Tepi

Deteksi tepi bertujuan untuk mengetahui pola tepi dari tulang paha yang akan diuji. Setiap titik pada gambar akan dibandingkan dengan titik disekitarnya untuk menentukan apakah titik tersebut merupakan tepi atau bukan. Jika suatu titik memiliki perbedaan yang tinggi dengan titik

disekitarnya, maka titik tersebut akan dikatakan sebagai tepi. Pendeteksian tepi menggunakan pendekatan algoritma Canny dilakukan dengan konvolusi fungsi image dengan operator Gaussian dan turunan-turunannya. Hasil dari deteksi tepi ditunjukkan pada Gambar 5 di bawah ini:

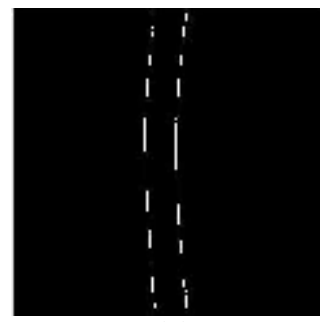

(a)

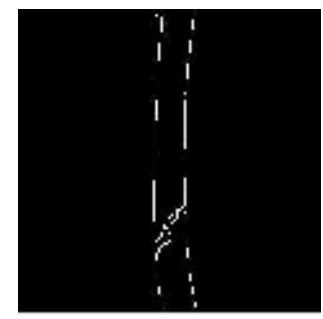

(b)

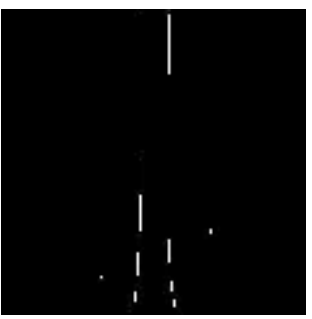

(c)

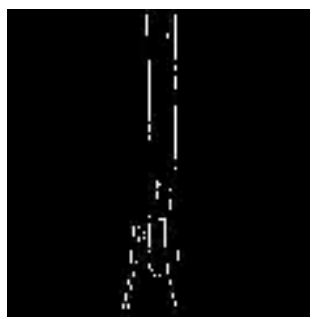

(d)

Gambar 5. Hasil deteksi tepi (a) Posisi tulang lateral tidak cacat, (b) Posisi tulang lateral cacat, (c) Posisi tulang AP tidak cacat, (d) Posisi tulang AP cacat

4. Mengubah citra hasil deteksi tepi menjadi biner

Citra hasil deteksi tepi merupakan citra grayscale, sehingga perlu diubah menjadi biner untuk keperluan proses selanjutnya. Pengambangan yang digunakan adalah 0.5 yang artinya semua pixel yang nilainya di atas 0.5 diubah menjadi bernilai 1 , dan lainnya diubah menjadi bernilai 0 .

5. Hitung distribusi frekuensi kumulatif relatif dari citra uji dan citra acuan

Distribusi frekuensi kumulatif relatif citra dihasilkan dari penghitungan jumlah pixel putih pada setiap baris citra biner yang telah dihasilkan pada proses sebelumnya. Pixel putih adalah pixel yang mempunyai nilai 1 pada citra biner. Ditribusi frekuensi dari pixel putih inilah yang akan digunakan untuk pegujian citra apakah terjadi fraktur ataupun tidak dengan cara membandingkan antara distriusi frekuensi pixel putih citra uji dengan distribusi frekuensi pixel putih citra acuan yang terdapat pada database. Berikut adalah grafik dari distribusi frekuensi kumulatif relatif pixel putih citra tulang paha seperti yang diperlihatkan dalam Gambar 6. 


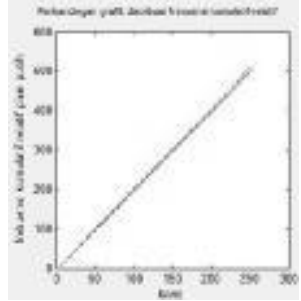

(a)

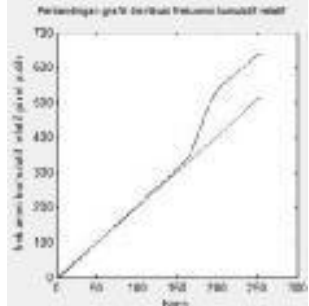

(b)

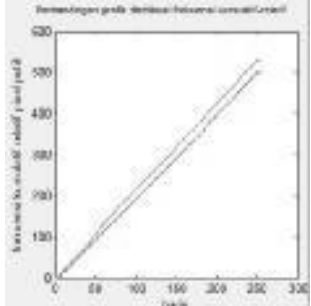

(c)

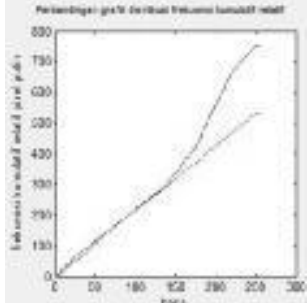

(d)

Gambar 6. Perbandingan grafik distribusi frekuensi kumulatif relatif (a) Posisi Lateral tidak cacat, (b) Posisi Lateral cacat, (c) Posisi AP tidak cacat, (d) Posisi AP cacat

6. Uji kolmogorov smirnov

Proses selanjutnya adalah ujikolmogorov smirnov, yaitu suatu metode pengujian normalitas dari suatu distribusi. Pada matlab uji kolmogorov smirnov menggunakan sintaks kstest 2 . Fungsi kstest 2 ini akan menghasilkan keluaran 0 dan 1 . Jika nilainya 0 maka hipotesis awal diterima yang berarti tulang tidak mengalami fraktur, sedangkan jika nilainya 1 maka hipotesis awal ditolak yang berarti tulang mengalami fraktur.

\subsection{Hasil Deteksi}

Citra yang digunakan dalam proses pengujian adalah citra baru dimana bukan merupakan citra yang dijadikan acuan. Jumlah citra uji ada 29 citra. Citra uji dibagi menjadi 2 jenis: sebanyak 15 citra tulang paha dengan posisi Antero Posterior, dan 14 citra tulang paha dengan posisi Lateral.

Tabel 2. Hasil deteksi citra tulang paha posisi Antero Posterior

\begin{tabular}{|c|c|c|c|c|}
\hline No & Nama File & Kondisi Tulang & Hasil Deteksi & Keterangan \\
\hline 1. & AnteroPosterior A1.jpg & Tidak Cacat & Tidak Cacat & Sesuai \\
\hline 2. & AnteroPosterior A2.jpg & Tidak Cacat & Cacat & Tidak Sesuai \\
\hline 3. & AnteroPosterior A3.jpg & Tidak Cacat & Tidak Cacat & Sesuai \\
\hline 4. & AnteroPosterior A4.jpg & Tidak Cacat & Tidak Cacat & Sesuai \\
\hline 5. & AnteroPosterior A5.jpg & Tidak Cacat & Cacat & Tidak Sesuai \\
\hline 6. & AnteroPosterior B1.jpg & Cacat & Cacat & Sesuai \\
\hline 7. & AnteroPosterior B2.jpg & Cacat & Cacat & Sesuai \\
\hline 8. & AnteroPosterior B3.jpg & Cacat & Cacat & Sesuai \\
\hline 9. & AnteroPosterior B4.jpg & Cacat & Cacat & Sesuai \\
\hline 10. & AnteroPosterior B5.jpg & Cacat & Cacat & Sesuai \\
\hline 11. & AnteroPosterior B6.jpg & Cacat & Cacat & Sesuai \\
\hline 12. & AnteroPosterior B7.jpg & Cacat & Tidak Cacat & Tidak Sesuai \\
\hline 13. & AnteroPosterior B8.jpg & Cacat & Cacat & Sesuai \\
\hline 14. & AnteroPosterior B9.jpg & Cacat & Cacat & Sesuai \\
\hline 15. & AnteroPosterior A6.jpg & Tidak Cacat & Tidak Cacat & Sesuai \\
\hline
\end{tabular}


Tabel 3. Hasil deteksi citra tulang paha posisi Lateral

\begin{tabular}{|c|c|c|c|c|}
\hline No & Nama File & Kondisi Tulang & Hasil Deteksi & Keterangan \\
\hline 1. & Lateral A1.jpg & Tidak Cacat & Tidak Cacat & Sesuai \\
\hline 2. & Lateral A2.jpg & Tidak Cacat & Tidak Cacat & Sesuai \\
\hline 3. & Lateral A3.jpg & Tidak Cacat & Tidak Cacat & Sesuai \\
\hline 4. & Lateral A4.jpg & Tidak Cacat & Cacat & Tidak Sesuai \\
\hline 6. & Lateral B1.jpg & Cacat & Cacat & Sesuai \\
\hline 7. & Lateral B2.jpg & Cacat & Cacat & Sesuai \\
\hline 8. & Lateral B3.jpg & Cacat & Cacat & Sesuai \\
\hline 9. & Lateral B4.jpg & Cacat & Tidak Cacat & Tidak Sesuai \\
\hline 10. & Lateral B5.jpg & Cacat & Cacat & Sesuai \\
\hline 11. & Lateral B6.jpg & Cacat & Cacat & Sesuai \\
\hline 12. & Lateral B7.jpg & Cacat & Cacat & Sesuai \\
\hline 13. & Lateral B8.jpg & Cacat & Cacat & Sesuai \\
\hline 14. & Lateral B9.jpg & Cacat & Cacat & Sesuai \\
\hline 15. & Lateral B10.jpg & Cacat & Cacat & Sesuai \\
\hline
\end{tabular}

Untuk menghitung tingkat akurasi sistem yaitu dengan membagi jumlah citra yang berhasil dikenali dengan jumlah keseluruhan citra yang dideteksi kemudian dikalikan 100\%. Hasil akurasi dari deteksi citra tulang paha bisa dilihat pada perhitungan di bawah ini:

Untuk citra tulang paha dengan posisi Anterior Posterior (AP), perhitungan akurasinya sebesar $80 \%$ sedangkan untuk citra tulang paha dengan posisi Lateral, perhitungan akurasinya sebesar $86.7 \%$

\section{Kesimpulan}

Berdasarkan dari hasil pembahasan tentang Aplikasi Pengolahan Citra untuk Mendeteksi Fraktur pada Tulang dengan Metode Canny dapat diambil beberapa kesimpulan, antara lain sebagai berikut :

1. Metode Canny Edge Detection dapat dimanfaatkan untuk mendeteksi fraktur pada tulang paha dengan memanfaatkan distribusi frekuensi pixel putih sebagai parameter proses deteksi.

2. Hasil penelitian menunjukan bahwa sistem yang dibangun berhasil melakukan deteksi fraktur pada tulang paha dengan nilai akurasi $80 \%$ untuk tulang paha dengan posisi Antero Posterior (AP) dan $86,7 \%$ untuk tulang paha dengan posisi Lateral. 


\section{DAFTAR PUSTAKA}

Achmad, B; Firdausy, K. 2005. Teknik Pengolahan Citra Digital Menggunakan Delphy. Yogyakarta: Andi Publishing.

Anita, I. 2012. Asuhan Keperawatan Pada Sdr.I dengan Fraktur Tibia di Ruang Kenanga RSI PKU Muhammadiyah Pekajangan Kabupaten Pekalongan. Pekalongan : STIKES Muhammadiyah Pekajangan.

Astuti, F. 2003. Pengolahan Citra Digital. Yogyakarta: Penerbit Andi.

Febriyana, Dita, 2012, Asuhan Keperawatan Post Operasi Orif Fraktur Tibia hari ke dua Pada Tn. M di Ruang Wijaya Kusuma Kraton Kabupaten Pekalongan, STIKES Muhammadiyah Pekajangan, Pekalongan

Hasan, M.I. 2003. Pokok Materi Statistik 2: Statistik Inferensif. Jakarta: Bumi Aksara

Indrawati. Segmentasi citra $x$-ray dari citra CT menggunakan active contour. Lhoksumawe: Politektik Negeri Lhoksumawe.

Isnanto, Rizal. 2003. Teknik Teknik Analisis Pada Citra Tulang Sebagai Alat Bantu Identifikasi Medis. Semarang: Universitas Diponegoro.

Is Mardianto; Dian Pratiwi. 2008. Sistem Deteksi Penyakit Pengeroposan Tulang Dengan Metode Jaringan Syaraf Tiruan Backpropagation Dan Representasi Ciri Dalam Ruang Eigen. Jakarta: Universitas Trisakti.

Melly, B. 2010. Analisis Kinerja Menggunakan Metode Canny Dalam Mendeteksi Tepi Karies Gigi. Sumatera: Universitas Sumatera Utara.

Mustika, M.H. 2009. Aplikasi Perbaikan Citra Digital untuk Mengidentifikasi Kerusakan/Cacat pada Film Radiografi Sambungan Las. Skripsi-S1. Yogyakarta: Program Studi Teknik Informatika UAD.

Muhtadan, D.H. 2008. Pengembangan Aplikasi Untuk Perbaikan Citra Digital Film Radiografi. Seminar Nasional IV- Teknologi Tenaga Nuklir

Noviardy. 2012. Kesehatan Tulang: Kasus Patah Tulang Cenderung Meningkat. Available : http://lifestyle.bisnis.com/read/ 20121012/54/99878 /kesehatan-tulang-kasus-patah-tulangakibat-osteoporosis-cenderung-meningkat (diakses pada tanggal 11 Juni 2014)

Watiningsih, Tri. 2012. Pengolahan Citra Foto Sinar-X Untuk Mendeteksi Kelainan Paru. Teodolita IV . Riset Kesehatan Dasar (RIKERDAS) 2007.2008. Badan Penelitian dan Pengembangan Kesehatan Departemen Kesehatan RI.
2012. Pengolahan
Citra
Tugas
4.
available

(diakses pada

http://mochamadyagi.wordpress.com/2012/04/17/pengolahan-citra-tugas-4/ tanggal 18 Maret 2014) 